\title{
Government Control of Information
}

\section{Citation}

Cass R. Sunstein, Government Control of Information, 74 Calif. L. Rev. 889 (1986).

\section{Published Version}

http://scholarship.law.berkeley.edu/californialawreview/vol74/iss3/10/

\section{Permanent link}

http://nrs.harvard.edu/urn-3:HUL.InstRepos:12911343

\section{Terms of Use}

This article was downloaded from Harvard University's DASH repository, and is made available under the terms and conditions applicable to Other Posted Material, as set forth at http:// nrs.harvard.edu/urn-3:HUL.InstRepos:dash.current.terms-of-use\#LAA

\section{Share Your Story}

The Harvard community has made this article openly available.

Please share how this access benefits you. Submit a story.

\section{Accessibility}




\title{
California Law Review
}

Volume 74 | Issue 3

Article 10

May 1986

\section{Government Control of Information}

\author{
Cass R. Sunstein
}

Follow this and additional works at: http://scholarship.law.berkeley.edu/californialawreview

\section{Recommended Citation}

Cass R. Sunstein, Government Control of Information, 74 CAL. L. Rev. 889 (1986).

Available at: http://scholarship.law.berkeley.edu/californialawreview/vol74/iss3/10

This Article is brought to you for free and open access by the California Law Review at Berkeley Law Scholarship Repository. It has been accepted for inclusion in California Law Review by an authorized administrator of Berkeley Law Scholarship Repository. For more information, please contact jcera@law.berkeley.edu. 


\section{Government Control of Information}

\section{Cass R. Sunstein $\dagger$}

Government secrecy has been a frequent source of pubhic concern over the last two decades. The bombing of Cambodia in 1969 was kept secret from the public, as were the plans for the invasion of Grenada in 1985. The Watergate scandal revealed a long hist of abuses, not disclosed to the public, in the doinestic and foreign arenas. The Freedom of Information Act was intended to limit government control of information, but the statute has hardly ensured disclosure of all important governmental practices and decisions. ${ }^{1}$ Claims that the first amendinent guarantees a right of access to information held by government have usually been rejected. $^{2}$

The practice of withholding information when important public policies so require is nothing new; the Constitution's framers themselves kept their deliberations secret. But an important strand in American tradition leads in the opposite direction. Woodrow Wilson, for example, wrote that "government ought to be all outside and no inside. ... [T]here ouglit to be no place where anything can be done that everybody does not know about."3

This conflict accounts for the tension between a widely accepted understanding of the function of the first amendment and the current approach for accommodating the interest in disclosure and the need for secrecy. The understanding, reflected in Wilson's statement and associated with Alexander Meiklejohn, ${ }^{4}$ is that the first amendment is primarily designed to ensure citizen dehiberation about public affairs. Under

$\dagger$ Professor of Law, University of Chicago. B.A. 1975, Harvard College; J.D. 1978, Harvard Law School. This essay is a revised version of a speech delivered on the occasion of the 200th anniversary of the John Peter Zenger trial at a conference sponsored by the Annenberg School of Communications and the University of Pennsylvania Law School in October 1985. The author would like to thank Albert A. Alschuler, Douglas Baird, Richard A. Epstein, James P. Holzhauer, Richard A. Posner, Frederick P. Schauer, Geoffrey R. Stone, and David A. Strauss for helpful comments on an earlier draft. Jeremy Friedman provided valuable comments and research assistance.

1. See $1 \mathrm{~K}$. Davis, Administrative Law Treatise $\S 4.45$, at $442-46$ ( $2 \mathrm{~d}$ ed. 1978).

2. See, e.g., Pell v. Procunier, 417 U.S. 817 (1974); Saxbe v. Washington Post Co., 417 U.S. 843 (1974).

3. W. WiLSON, The NEW FREedoM 113-14 (1913); see also id. at 130 ("Government must, if it is to be pure and correct in its processes, be absolutely public in everything that affects it.").

4. See A. Meiklejohn, Free Speech and Its Relation to Self-Government 24-27 (1948). Others have also based arguments on this model. See, e.g., BeVier, The First Amendment and Political Speech: An Inquiry Into the Substance and Limits of Principle, 30 STAN. L. REv. 299 (1978). 
this view, the citizenry must have a significant role in government decisions, and the guarantee of freedom of expression is intended above all to promote that role.

The approach might be called an equilibrium model of the first amendment. Under this model, government is under no general obligation to disclose information, but the press may pubhish whatever material it is able to acquire. Sometimes the equilibrium approach is based on the text and history of the first amendment; 5 sometimes it is offered as an easily administered system for accommodating the need for secrecy and the value of disclosure without sacrificing either. ${ }^{6}$ In both cases, the absence of a right of access to information held by the government is balanced by the power to publish almost all information that has been lawfully obtained. The self-interested behavior of countervailing forces, it is thought, will produce an equilibrium that benefits the citizenry as a whole.

This Article explores whether the equilibriuin theory adequately accommodates the need for secrecy and the goal of ensuring citizen deliberation about issues of public importance. After describing the principal reasons for and against government secrecy, the Article explains why a struggle between the press and the government is unlikely to produce an acceptable "equilibrium." The Article then discusses governinent control of privately generated "technical data" and of speech by public employees, two sharply disputed first amendinent issues. An exploration of these issues supports the general conclusion that the equilibriun theory serves neither the need for secrecy nor the value of public deliberation about public affairs. The Article concludes with some suggestions for reformulation of the equilibriuin theory.

\section{I}

\section{The JefFersonian Model of FreE EXPRESSION}

The popular understanding of the function of the first ainendment derives froin a conception of free speech associated with Thoinas Jefferson. ${ }^{7}$ The premise of this conception is that the purpose of free

5. See BeVier, An Informed Public, an Informing Press: The Search for a Constitutional Principle, 68 CALIF. L. Rev. 482 (1980).

6. See A. Bickel, THE Morality of Consent 79-83 (1975).

7. It was Jefferson who, among the Founders, most powerfully emphasized the value of deliberative processes among the citizenry. For a general discussion of Jefferson's views, sec $\mathrm{H}$. ARENDT, ON REVOLUTION 234-42 (1963); see also infra note 29 (noting Jefferson's regret that the framers closed the Convention). This position is distinct from that of Madison and other prominent writers at the time of the framing, who argued for deliberation by representatives rather than by the citizenry as a whole. See Sunstein, Interest Groups in American Public Law, 38 StaN. L. Rev. 29, 38-43 (1985).

The model has important competitors, which stress, among other things, the value of speech in promoting self-realization, see Redish, The Value of Free Speech, 130 U. PA. L. Rev. 591 (1982); 
expression is to ensure to the extent possible that the citizenry will make informed decisions on public issues. For intelligent popular decisionmaking, there must be widespread public deliberation in advance. Before government sends troops to a foreign country or regulates risks in the workplace, there should be an opportunity for general discussion. The Jeffersonian model thus views deliberation as a critical element in the system of self-government.

Under this view, one of the central functions of politics is the selection of social preferences, ratlier than the mechanical implementation of majority will. Deliberative processes used by citizens and representatives are the key elements im the system. ${ }^{8}$ For example, a law prohibiting discrimination on the basis of race, gender, or handicap might derive, not from preexistmg private preferences, but from a decision, reached after public discussion, that discrimination of that sort is unjustifiable. More generally, a law might reflect a decision tliat some preferences ought not to be satisfied. ${ }^{9}$

This view, of course, imphes that the political process sliould not always take private "interests" for granted and assume that the purpose of the system is to aggregate or balance those interests. Properly understood, the system is not one in whicl private groups press their private interests on government. Instead, the Jeffersonian approach implies that there is in some contexts a cominon good, emerging after processes of free expression and debate, that is distinct from the aggregation or tradeoff of private preferences. Public deliberation, helping to create a political community, is a crucial means of ensuring that the common good is brought about. ${ }^{10}$

Scanlon, $A$ Theory of Freedom of Expression, 1 PHIL. \& PUB. AFF. 204 (1972), the contribution of speech to the marketplace of ideas, see Abrams v. United States, 250 U.S. 616, 630 (1919) (Holmes, J., dissenting), and the role of speech in the discovery and spread of truth, see J. MILI, ON LIBERTY 31-67 (1859). A large literature attempts to explicate one or another of these various understandings. See, e.g., L. BoliINGER, The Tolerant SocIETY 43-75 (1986) (criticizing classical approaches); F. SCHauer, Free SPEech: A Philosophical EnQuiry 15-72 (1982) (analyzing various understandings of free speech); Bork, Neutral Principles and Some First Amendment Problems, 47 IND. L.J. 1, 20-35 (1971) (advocating that constitutional protection be extended only to political speech).

8. Cf. Pitkin, Justice: On Relating Private and Public, 9 POL. THEORY 327, $342-46$ (1981). Pitkin suggests: "Only in public life can we jointly, as a community, exercise the human capacity "to think what we are doing' and take charge of the history in which we are all constantly engaged by drift and inadvertence." Id. at 344 (footnote omitted).

9. The story of Ulysses and the Sirens is an apt metaphor. See J. ELSTER, UlYSSES AND THE Sirens: Studies in RATIONALITY AND IRRATIONALITY 36-38 (1979) (discussing autopaternalism). Note that this argument is not that some people may impose their preferences on others; it is instead that people may decide that they wish to ensure that their own short-run preferences are not satisfied. Cf. id. at 84-85 (discussion of persuasion); see also generally Sunstein, Legal Interference with Private Preferences, 53 U. CHI. L. REv. (forthcoming 1986) (discussing private preferences and the law).

10. Cf. Pitkin, supra note 8 , at $342-46$ (discussing functions of political deliberation). Pitkin 
Two general constitutional themes underlie the Jeffersonian conception of free speech. The first is the effort to ensure against self-interested representation: attempts by representatives to achieve personal goals that diverge from the interests of the citizenry. ${ }^{11}$ Public disclosure and discussion operate as a check on the conduct of representatives, thereby supplementing electoral control. ${ }^{12}$ Government secrecy should be distrusted, for if information is withheld from the public, an inportant limitation on self-interested representation will be eliminated.

The second theme concerns the risk of usurpation of government by private factions. ${ }^{13}$ Public discussion, subjecting both governmental processes and private preferences to critical scrutiny, should reduce the likeliliood that powerful private groups will have undue influence over the processes of government. The first amendment is thus designed to inake it more likely that government decisions will be a product of public dehiberation rather thian factional pressure. In both of these respects, the amendment may be understood as a structural provision, ensuring certain government processes; its purposes extend well beyond the protection of private autonomy.

If the Jeffersonian model is accepted, all material that communicates is not, by virtue of thiat fact, entitled to the highest level of constitutional protection, demanding a justification from government akin to that set out in the Pentagon Papers case. ${ }^{14}$ Perliaps the clearest example is commercial speech, ${ }^{15}$ defined as advertising or speech that proposes a business transaction. ${ }^{16}$ Commercial speech is not entirely deprived of first amendinent protection; to regulate it, the government must meet some

notes, "What distinguishes public life is the potential for decisions made not merely in the name of the whole community but actually by that community collectively, through participatory political action, and in the common interest." Id. at 344 (emphasis in original). Cf. also J. ELSTER, SouR GRAPES 33-42 (1983) (discussing collective rationality).

11. Cf. The Federalist No. 47 (J. Madison), No. 51 (A. Hamilton or J. Madison) (risk of tyranny diminished by separation of powers); F. SCHAUER, supra note 7, at 38-39, $43-44$ (justifying special protection of speech with reference to likelihood that government will be acting for illegitimate reasons); Blasi, The Checking Value in First Amendment Theory, 1977 AM. B. FouND. RESEARCH J. 521 (free speech can serve to check abuse of power).

12. Cf. J. ELY, DEMOCRACY AND DISTRUST 105 (1980) (first amendment rights are critical to functioning of democratic process).

13. See The Federal1st No. 10 (J. Madison).

14. New York Times Co. v. United States, 403 U.S. 713 (1971). For a description of this standard, see infra text accompanying note 42.

15. See Virginia State Bd. of Pharmacy v. Virginia Citizens Consumer Council, Inc., 425 U.S. 748, 762 (1976) (commercial speech entitled to some first amendment protection); Baker, Commercial Speech: A Problem in the Theory of Freedom, 62 IowA L. REv. 1 (1976) (arguing against constitutional protection of commercial speech); Jackson \& Jeffries, Commercial Speech: Economic Due Process and the First Amendment, 65 VA. L. Rev. 1 (1979) (same).

16. Cf. Central Hudson Gas \& Elec. Corp. v. Public Serv. Comm'n, 447 U.S. 557, 561 (1980) (commercial speech defined as "expression related solely to the economic interests of the speaker and its audience"). 
burden of justification. That burden, however, is substantially less severe than the Pentagon Papers standard. ${ }^{17}$ The reason for the lower level of protection is that commercial speech is far removed from the central concerns of the first amendment; as a result, the government need not meet the usual heavy burden of justification. ${ }^{18}$

The Jeffersonian model is also extremely optimistic about the effects of free speech. Some have suggested that this optimism is unwarranted in light of the ability of representatives and private groups to structure public discussion so that it is threatening to neither of them. ${ }^{19}$ Public and private power inevitably weakens the autonomy of deliberative processes; open discussion, while formally egalitarian, gives some factions an opportunity to dominate the process. ${ }^{20}$ In these circumstances, the Jeffersonian model should be treated as aspirational rather than as a reflection of actual practice.

Finally, the Jeffersoman model oversimplifies the constitutional system, which delegates authority to representatives as well as to citizens. Pohtical decisions are generally made not by the people themselves, but

17. For example, commercial speech may be suppressed simply because it is false or misleading. See id. at 563-64. A recent Umited States Supreme Court case suggests highly deferential review of legislative regulation of commercial speech. Posadas de Puerto Rico Associates v. Tourism Co. of Puerto Rico, 106 S. Ct. 2968 (1986).

18. This theme is of course a familiar one in first amendment doctrine. Obscemity, for example, is subject to regulation on a similar ground, see Roth v. United States, 354 U.S. 476, 484-85 (1957) (obscenity not protected as it is "utterly without redeeming social importance"); see also Miller v. California, 413 U.S. 15, 20-24 (1973) (reaffirming Roth), as are false statements of fact, see Gertz v. Robert Welch, Inc., 418 U.S. 323, 340 (1974), "fighting words," see Chaplimsky v. New Hainpshire, 315 U.S. 568, 571-74 (1942), and other categories of unprotected speech. See generally G. STONE, M. Seidman, C. Sunstein, \& M. Tushnet, Constitutional Law ch. 7 (1986) (discussing categories of low-value speech).

The controversial notion that some speech should be afforded less protection because of its "Iow value" is discussed infra, text accompanying notes 76-79.

19. See, e.g., H. MARcuse, Repressive Tolerance, in A Critique of PURE Tolerance 81, 9597 (1965) (arguing that relevant actors define debate so rigidly that outcome is foregone conclusion); Clark, Liberalism and Pornography, in PORNOGRAPHY AND CENSORSHIP 45 (D. Copp \& S. Wendell eds. 1983) (the "negative liberty" justification for pornography obscures its role in preserving the preexisting inequality between men and women).

20. See S. Lukes, Power: A Radical View 36-37 (1974); MacKinnon, Pornography, Civil Rights, and Speech, 20 HARV. C.R.-C.L. L. REV. 1 (1985) (challenging traditional approaches in the context of pornography, where "more speech" is not a remedy); Wright, Politics and the Constitution: Is Money Speech?, 85 YALE L.J. 1001, 1013-19 (1976) (justifying limits on political contributions by arguing that size of contribution not correlated to intensity of feelings and that uncontrolled systein gives undeserved weight to wealthy, organized entities). The Jeffersonian model, seeking to promote decisionmaking that is in important respects autonomous, or distinct from relations of power, is based on assumptions that those engaged in debate are equal, enjoy mutual respect, and have agreed to the terms of the discussion, as in Habermas's "ideal speech situation." See Habermas, Towards a Theory of Communicative Competence, 13 INQUIRY 360, 37172 (1970). For this reason the model is vulnerable to critiques stressing the relationship between knowledge and power. See J. ELSTER, supra note 10, at 33-42; J. KEANE, Public Life AND LATE CAPITALISM 184-86 (1984); see also generally M. FoucaulT, PoWER/KNOWLedge (1980) (discussing dependence of knowledge on constellations of power). 
by officials who are subject to electoral and other kinds of control. In these circumstances it is hard to justify the idea that full public disclosure, $m$ the interest of ensuring decision by the citizenry, is always necessary or desirable. The Jeffersonian understanding thus tends to undervalue the representative character of the constitutional scheme.

At the same time, however, the Jeffersonian understanding properly emphasizes the need for citizen supervision of the representative's decisionmaking processes. ${ }^{21}$ Even if the model undervalues the function of representation, it correctly focuses on the salutary effects of citizen deliberation. If information is kept secret, public deliberation cannot occur; the risks of self-imterested representation and factional tyranny increase dramatically. The Jeffersonian model thus calls for substantial limitations on governmental secrecy.

II

\section{SECRECY AND DISCLOSURE}

Even if it is agreed that citizens should generally be able to deliberate about government action, the need for secrecy sonietimes justifies government control of information. This need niay apply to many types of information from widely diverse sources. Sometimes the information has been privately generated; sometimes it comes from government employees. Sometimes it consists of information; sometimes it consists of a point of view. It will be useful to begin by identifying some of the types of niaterials that government might seek to restrict.

One kind of information that government is interested in controlling concerns military or diplomatic secrets. These include both proposed courses of action - which, if disclosed, would no longer be effective-and current conduct of which an adversary is unaware. Examples include covert operations aimed at influencing political outcomes in foreign countries, including the bribery of foreign officials. Another category is "technical data": scientific information with actual or potential military applications. This information may come either from the government itself or fronı private citizens. Government might also wish to keep secret the contents of deliberations among public officials.

A central consideration here is that all of this speech is trueindeed, that is part of the definition of much of the "information" that governnient seeks to control. Ordinarily in first amendment law, speech is unprotected either because it is false or because it serves not at all, or only tangentially, the underlying purposes of the first amendment. Thus, for example, false statenients ${ }^{22}$ and obscenity ${ }^{23}$ are generally unprotected.

21. See supra text accompanying notes 11-13.

22. See Gertz v. Robert Welch, Inc., 418 U.S. 323, 340 (1974). 
In the examples at hand, however, government is seeking to suppress speech precisely because it is true. If technical data did not lead to military or scientific progress, or if information about the status of covert operations were false, there would be less need to censor it. Moreover, most of this speech concerns the operation of the political system and thus falls close to the heart of the Jeffersoman understanding.

In these circumstances, identification of the reasons for suppression is an important step in evaluating governmental efforts to control information. The reasons, sometimes invoked in the cases, fall into five categories.

1. Protecting military plans. Disclosure of military plans or facts will of course increase vulnerability; if an adversary knows what we are doing, it will be harder for us to do it. The same is true of disclosure of "technical data" that will promote the military capability of the adversary.

2. Facilitating negotiations. Disclosure may inhibit flexibility in bargaining during the process of decisionmaking. If bargaiming positions are revealed to the public, views may harden, and the participants will be less likely to arrive at a mutually acceptable accommodation. ${ }^{24}$

3. Facilitating uninhibited deliberations within government. Secrecy tends to promote uninhibited discussion of pohcy options, not only in the negotiating process, but also during discussions with coworkers and superiors. If decisionmaking processes were exposed to public view, disagreements and controversial views might not be aired at all. ${ }^{25}$ Similarly, a group is unlikely to develop a coherent position if it is unable

23. Roth v. United States, 354 U.S. 476, 484-85 (1957); see also Miller v. California, 413 U.S. 15, 20-21 (1973) (quoting Roth).

24. See S. Box, SECRETS 184 (1982). This justification played a central role in the framers' decision to ensure secrecy in the discussions that led to the Constitution. Among the first rnles adopted at the Convention was an injunction against publicizing the framers' deliberations. $1 \mathrm{M}$. FARRAND, The Records of the Federal Convention of 1787, 17 (1911). In Madison's view, such secrecy was a necessary predicate to adoption of the Constitution. He explained that it was best

to sit with closed doors, because opinions were so various and at first so crude that it was necessary they should be long debated before any uniform system of opinion could be formed. Meantime the minds of the members were changing, and much was to be gained by a yielding and accommodating spirit. Had the members committed themselves publicly at first, they would have afterwards supposed consistency required them to maintain their ground, whereas by secret discussion no man felt himself obliged to retain his opinions any longer than he was satisfied of their propriety and truth, and was open to the force of argument.

3 Id. at 479 . This rationale is tightly connected with Madison's conception of governance. According to that conceptiou, representatives rather than citizens at large were to engage in deliberation. See generally Sunstein, supra note 7, at 38-43 (discussing departure of Madisonian thought from traditional republicanism). Characteristically, Jefferson rejected this view. See infra note 29.

25. This understanding underlies the principle of executive privilege. See United States v. Nixon, 418 U.S. 683, 705 (1974). 
to explore, with some tentativeness, the disparate options with which it is confronted.

4. Avoiding interest-group pressures. If deliberations are disclosed while they are in progress, organized groups with intense preferences may attempt to influence the outcome. Interest-group pressures could transform a dehiberative process into an effort to trade off the interests of powerful, well-organized private groups. Secrecy can prevent such pressures from coalescing and serve to help representatives seek a public good, based on what Madison called the "force of argument," which is distinct from the balancing of preexisting interests. For this reason, secrecy may sometimes alleviate rather than aggravate the problem of factional tyranny. ${ }^{26}$

5. Avoiding distrust and suspicion; encouraging communications from others. Disclosure, even of past conduct, may breed distrust among allies and adversaries alike and may make people less willing to provide confidential information. In the foreigu relations context, it may be important to keep military projects secret. We may be engaging in conduct that some countries disapprove, even though the conduct is welcomed by others and is generally in the national interest; disclosure may compromise traditional alliances and the plans themselves. ${ }^{27}$ Domestically, the Federal Bureau of Investigation would be less able to attract informants if it were unable to assure them that their identities, and perhaps the contents of their communications, would be kept from the public. Privacy interests may also call for secrecy. Examples are the government's refusal to disclose the records of the Internal Revenue Service, the names of rape victims prior to the filing of a court action, ${ }^{28}$ and the confessions of defendants currently on trial.

To outline the disadvantages of disclosure is hardly to deny that in some contexts disclosure will have significant benefits as well. Like the disadvantages, the benefits fall into five categories.

1. Citizen deliberation. Secrecy prevents the public from making decisions after deliberation. In this respect, it is inconsistent with the principle of self-rule. ${ }^{29}$ Secrecy may thus underinine the central purposes

26. Ironically, one of the purposes of a system of free expression is to ensure that governmental decisions are the product of the force of argument rather than of a struggle of private interests; but in some contexts, disclosure will work against that same purpose.

27. Henry Kissinger voiced this concern in disapproving of Daniel Ellsberg's decision to release the Pentagon Papers. "The massive hemorrhage of state secrets was bound to raise doubts about our reliability in the minds of other governments, friend and foe, and indeed about the stability of our political system." H. Kissinger, White House YeArs 730 (1979).

28. But see Cox Broadcasting Corp. v. Cohn, 420 U.S. 469 (1975) (state prohibition of publishing rape victims' names obtained from public records unconstitutional).

29. Jefferson, invoking this ground, regretted that by closing the Constitutional Convention, the framers "began their deliberations by so abominable a precedent as that of tying up the tongues of their members. Nothing can justify this example but the innocence of their intentions, and 
of the Jeffersonian system: preventing self-interested representation and the usurpation of government power by private factions.

2. Checks and balances. Secrecy may distort the systent of checks and balances in the structure of the federal government. It will be very difficult, if not inipossible, for the legislature to monitor the activities of the executive branch if information is concentrated there. This consideration is especially important in light of the increasing power of the President in the field of foreign affairs. ${ }^{30}$ If Congress is to play a role, it must have the relevant facts. Although this rationale may not justify disclosure to the public at large, it argues agamst executive control of information.

3. The deterrent effect of disclosure. In some circunistances, disclosure of military capabilities will actually increase national security. An adversary who is aware of current strengths will be less likely to undertake aggressive action. Disclosure of certain pieces of information inay also facilitate technological advances. An example is the suggestion that the failure to advertise the developinent of radar was detrimental during World War II. ${ }^{31}$

4. Sunlight as a disinfectant. If deliberations are conducted in secret, the participants may be less careful to ensure that their behavior is unaffected by illegitimate or irrelevant considerations. Exposure will make it less likely that such considerations will influence public deliberations. ${ }^{32}$ In this sense, disclosure can gnard agaimst self-interested representation or the usurpation of government power by private groups. To say this, of course, is not to suggest that disclosure is a perfect safegnard; impermissible notivations may merely be concealed. But opening up the process should weaken their influence. The appearance of openness inay also promote popular trust in government.

5. "Use value" and progress. Information may improve social wel-

ignorance of the value of public discussions." Letter from Thomas Jefferson to John Adams (Aug. 30, 1787), reprinted in 1 THE ADAMS-JEFFERSON LETTERS 194, 196 (L. Cappon ed. 1959).

30. See, e.g., L. Henkin, Foreign Affalrs and the Constrtution (1972).

31. In the case of radar, secrecy seriously delayed its development .... As a consequence, although it was technically and demonstrably adequate to have done this relatively simple job, radar failed to prevent Pearl Harbor .... Had they known our radar protection of Pearl Harbor, there is at least a reasonable doubt that the Japanese would have attempted a surprise.

....

In any event, our shipping losses after [the] beginning [of the war] would certainly have been less than the tragic millions of tons.

Availability of Information from Federal Executive Agencies: Hearings Before the Special Subcomm. on Government Information of the House Comm. on Government Operations, 84th Cong., $2 \mathrm{~d}$ Sess. 757 (1956) (statement of L. Berkner); see also F. ROURKE, SECRECY AND PUBLICITY 222-24 (1961) (discussing this phenomenon).

32. The point is captured in Brandeis's remark, "Sunlight is said to be the best of disinfectants." L. Brandeis, OTHer People's Money 62 (1933). 
fare; it is valuable to those who use it; and it will tend to accelerate technological and other progress. In industry, science, and elsewhere, disclosure will enable people to accomplish tasks more quickly and easily, increase leisure time, obtain greater profits, and so forth. Information is in this respect frequently a valuable commodity. This rationale applies not only to speech about politics, but also to scientific, technological, and other information. All information is potentially valuable, whether or not it fits within the Jeffersonian framework.

\section{III}

\section{The Current Approach AND Its Shortcomings}

The problem of government control of information thus involves a broad array of conflicting considerations. If one were building the system afresh, one might approach the problein by examining which interests are present in any particnlar case. It would be possible, for example, to create a basic presumption in favor of publicity, but to allow secrecy if one or more of the various interests weigl heavily against it. To be sure, difficult problems would arise under such an approach. Sometimes there would be considerations on both sides; sometiines a particular argument for secrecy or disclosure would be weak in context. The Jeffersonian understanding might help to sinplify the inquiry, pointing as it does to the primacy of political speecl, broadly defined, and to the value of citizen deliberation on issues of public importance. But there would be hard intermediate cases, and serious questions of judicial competence would arise in balancing the relevant factors. The liope would be that by proceeding in a common law manner, courts could eventually generate broad rules to cover most cases.

Current doctrine, however, has generally taken a quite different approach. Rather thian assessing the relevant interests, that approach relies on the incentives of the press and the government to generate an equilibrium that will, in a inarket-like fashion, operate to benefit the public as a whole. The inodel, set out most crisply by Alexander Bickel, ${ }^{33}$ purports to describe the circumstances in which governinent's desire for secrecy will be opposed by the press's interest in disclosure. Bickel begins by noting that, as far as the first ainendment is concerned, "government is entitled to keep things private and will attain as mucl1 privacy as it can get away witl1 politically by guarding its privacy internally." 34 This power "to arrange security at the source, looked at in itself, is great, and if it were nowlere countervailed it would be quite frightening ...."35 Bickel notes, lowever, the existence of a "countervailing power"

33. See A. BICKEL, supra note 6, at 79-83.

34. Id. at 79.

35. Id. at 80 . 
which allows the government to prevent the press from publishing a story or pieces of information only im extreme and dire circumstances. This situation, Bickel concedes, is "disorderly," but it is preferable to a solution that would sacrifice either privacy or public discourse. Bickel concludes:

If we should let the government censor as well as withhold, that would be too much dangerous power, and too much privacy. If we should allow the government neither to censor nor to withhold, that would provide for too hittle privacy of decision-making and too much power in the press $\ldots .^{36}$

We might describe this approacl as an equilibrium theory of the first amendment. The idea is that the government and the press operate as coinpeting powers, armed with different incentives: the government seeks to maintain secrecy; the press seeks disclosure. This competition ensures that if both follow their self-interest, the resulting system will work, as if by an invisible hand, to benefit tlie public as a whole. The justification is similar to that which underlies the system of checks and balances in the structure of the federal government. ${ }^{37}$

Bickel's system has three clear doctrimal components that account for almost all of current law with respect to government control of information. The first component is a general demial of "access" rights. There is no right of access to information tlrat government has successfully withheld from the pubhic. In current law, the right of access to judicial proceedings is the ouly exception ${ }^{38}$ to this rule, and it is quite narrow. ${ }^{39}$ The second component is a general right to publish any information that the press has acquired-even if pubhication will undermine legitimate or indeed important governmental interests in secrecy. ${ }^{40}$ The third component of the system is a grant of permission for government to ban publication of information acquired by people in the private sector in "extreme and dire circumstances." Thus, for example, the minimal holding of the Pentagon Papers case ${ }^{41}$ is tliat the government can restrain the publication of information if disclosure "will surely result in direct, immediate, and irreparable dainage to our Nation or its people."42

36. Id.

37. See The Federalist No. 51 (A. Hamilton or J. Madison) (government structured so that each branch has power to keep others in their place). (1980).

38. This right was established in Richmond Newspapers, Inc. v. Virginia, 448 U.S. 555, 579-80

39. Note, however, that the enactment of the Freedom of Information Act, 5 U.S.C. $\$ 552$ (1982 \& Supp. II 1984), may have relieved the pressure for recognition of other constitutional access rights.

40. See Landmark Communications, Inc. v. Virginia, 435 U.S. 829, 844-45 (1978).

41. New York Times Co. v. United States, 403 U.S. 713 (1971).

42. Id. at 730 (Stewart, J., concurring). The standard for subsequent punishment may be somewhat lower, but it too requires a showing of certain and immediate harm. See Landmark 
The important question, of course, is whether the equilibrium approach to the first amendment well serves the Jeffersonian model of free expression, or more precisely, whether it usefully accommodates the need for secrecy as well as the interest in citizen deliberation. Under one view, the question is irrelevant: the first amendment is about suppression of speech, not about refusal to disclose information..$^{43}$ It is not possible to discuss this arguinent in detail here. ${ }^{44}$ For present purposes it will suffice to say that the constitutional text does not compel this conclusion, and that if the result depends on the intentions of the Constitution's drafters, it rests on controversial premises about constitutional interpretation..$^{45}$ In other contexts--some involving the first amendment itselfthe Court has departed froin text and history at least as dramatically as it would in recognizing a right of access. ${ }^{46}$ The justification for these departures is the conventional one: the extension is necessary in order to promote the underlying constitutional value. ${ }^{47}$ Even if a claim against rights of access based on text and history is accepted on its own terms, it is necessary to decide whether the equilibrium theory attributed to the first amendment is hikely to produce a sensible system of free expression, or whether it sacrifices the need for secrecy, the mterest in citizen deliberation, or both.

One virtue of the theory is that the lines it draws are for the most part quite well defined. The general denial of access rights, combined with the general denial of power to suppress materials once acquired, minimizes difficult problems of applying first amendment law in this area. If courts recognized rights of access in some circumstances, they

Communications, Inc. v. Virginia, 435 U.S. 829 (1978) (state ban on press reporting of investigation of judge unconstitutional); Brandenburg v. Ohio, 395 U.S. 444, 447-48 (1969) (advocaey of violence constitutionally protected except when intended to produce imminent lawless action).

43. See, eg., BeVier, supra note 5, at 497-516 (Constitution does not establish right of access).

44. There is ample writing on the subject. See, e.g., Baker, Press Rights and Government Power to Structure the Press, 34 U. MiAMI L. REv. 819 (1980) (arguing for and analyzing implications of independent interpretation of press clause based on checking value of media); BeVier, supra note 5 (arguing against press right of access); Lewis, $A$ Public Right To Know About Public Institutions: The First Amendment as Sword, 1980 SUP. CT. REv. 1, 22-24 (arguing for right of access to ensure government accountability).

45. See Brest, The Misconceived Quest for the Original Understanding, 60 B.U.L. REv. 204 (1980) (exploring various objections to "originalism"); Dworkin, The Forum of Principle, 56 N.Y.U. L. REv. 469, 471-500 (1981) (same).

46. For example, it is not clear that the first amendment was intended to extend far beyond prior restraint, see L. LEVY, EMERGENCE OF A FREE PRESS 268-73 (1985), and it is even more doubtful that its drafters intended it to aply to commercial speech, libel generally, and sexuallyoriented materials.

47. Such approaches are of course vulnerable to attack. See Easterbrook, Legal Interpretation and the Power of the Judiciary, 7 HARv. J.L. \& PUB. POL'Y 87 (1984) (arguing that judicial power must be connected to grants of authority). 
would face formidable questions of where to stop. ${ }^{48}$ A Pentagon Papers standard makes most cases of prior restraint and subsequent punishment quite simple-a considerable improvement over the open-ended balancing that characterized first amendment doctrine in earlier periods. ${ }^{49}$

But numerous other lines, almost as clear, could be drawn. A Pentagon Papers standard might, for example, be applied to all inforination requested by private citizens; the Freedom of Infornation $\mathrm{Act}^{50}$ could be a model here. The government might be required to justify nondisclosure by reference to one or more of the arguments set out above. The various considerations arguing for and against disclosure might eventually be developed into a series of bright-line rules, as has happeued elsewhere in first amendment law. ${ }^{51}$ And even if the equilibrium approach tends to generate distinctly administrable rules, it should be rejected if those rules are independently objectionable.

At the same time, the theory leaves a number of questions unanswered. One set of problems relates to the relevance of the methods by which private citizens obtain information. Suppose, for example, that a citizen acquires information unlawfully. Might government prohibit the publication of information thus acquired? Or suppose the information is obtained, not through private illegality, but through the unlawful conduct of a government official. Might government prevent its publication? ${ }^{52}$ Does it matter whether the private person was aware or should have been aware that the information was unlawfully acquired?

A second set of questions relates to the government's power to control the speech of its employees. Government cannot be defined apart from its agents. Does the government's power to "withhold" extend to the punishment of its own employees for breaches of secrecy? Are any constitutional questions raised by such sanctions? Problems of this sort suggest that the line between "withholding" and "censoring" will im some contexts be quite thin.

Questions of administrability to one side, there is no reason in the abstract to believe that the equilibrium approach well serves, or serves at all, the Jeffersonian or any other model of freedom of speech. Specifically, the equitibrium theory is vulnerable because it does not address three critical matters: the actual incentives of the press and the govern-

48. Cf. Brennan, Address, 32 Rutgers L. Rev. 173, 177 (1979) (protection of press in its performance of all its tasks is theoretically unlimited).

49. See, e.g., Dennis v. United States, 341 U.S. 494, 510 (1951) (test is whether gravity of evil discounted by probability of occurrence justifies punishment of speech).

50. 5 U.S.C. $\S 552$ (1982 \& Supp. II 1984).

51. See J. ELY, supra note 12, at 108-16.

52. The Pentagon Papers case suggests a negative answer. See New York Times Co. v. United States, 403 U.S. 713 (1971). 
ment; the respective power of the countervailing forces; and what the proper baseline for evaluating outcomes should be.

First, the equilibrium approach is premised on a particular understanding of the relevant incentives, in which government seeks to maintain secrecy and the press seeks disclosure; but the incentives are inuch more comphicated than the inodel suggests. Neither the governinent nor the press is unitary. Government is an abstraction, composed of many people. Soine employees will not single-mindedly pursue the goal of secrecy. Some will share interests with the press or seek to further their own careers and reputations. As a principal, "government" is able to exercise some control over its agents, but the officials who constitute government in this context themselves have coinplex incentives. As always, there are limits to the amount of control principals can exercise over their agents.

For its part, the press does not always have as an overriding incentive the revelation and disclosure of government misconduct. Alliances often develop between the press and the government. Most important, the principal institutional pressure of selling the product makes it unlikely that the press will venture too far from what its consunners want to read or hear. The press inust appeal to its own "constituency," and costly investigations inay not yield financial rewards. It is therefore unlikely that the press will always seek to uncover government misconduct. The system may thus fail to achieve an optimal level of disclosure.

To be sure, neither the press nor the constituency of readers and listeners is umitary, and the resulting diversity of consumer interests will increase the level and breadth of disclosure. But the conclusion that the incentives are inadequate is most powerful with respect to the inass media. The inass media has the greatest influence, ${ }^{53}$ and it will attempt to appeal to the wishes of mainstream consumers.

In general, then, the adversarial model on which the equilibriuin theory relies is both odd and inaccurate. It requires an assumption that the government and private speakers are locked in coinbat, with each trying constantly to undermine the other. It would be disturbing if such a picture mirrored reahty. The nornal expectations are that the press will at least soinetimes respect legitimate interests in secrecy, and that the government will often promote disclosure on its own. If the incentives diverge dramatically from what the equilibriuin model assumes, the model will break down.

Second, the equilibrium theory relies on an assumption that the countervailing forces possess sufficient power to offset one another, thus

53. See, e.g., Carter, Technology, Democracy, and the Manipulation of Consent, 93 YALE L.J. 581 (1984). 
providing an optimal level of disclosure. That assumption lacks support. In any particular period, government power to control disclosure inay, for example, overwhelm the citizenry's interest in public discourse. If so, the model will fail to serve the goal of ensuring against self-interested representation. Indeed, the notion that the government inay control information at its source is at odds with the idea that the purpose of a system of free expression is to control the conduct of representatives. ${ }^{54}$ On the other hand, the power of the press to acquire information may undermine the need for secrecy, especially if government is unable to control the behavior of its agents. The standard of justification for suppressing information under the equilibrium theory prevents censorship even of dangerous information.

Finally, it is always necessary with claims based on primciples of the invisible hand to have a baseline from which to make an evaluation. Is the baselime one in which the public has all information unless the various interests identified above require secrecy? How does one know whether the system is functioning properly? The equilibrium model offers no way to answer such questions.

These problems can be generalized into two powerful critiques of the equilibrium model. The first would suggest that the equilibrium theory undervalues the interest in secrecy in a way that will compromise important government interests. The system permits government suppression only in extraordimary circumstances. That conclusion may well, for example, foreclose government regulation of the commumication of technical data to foreign nations, notwithstanding the potential of such communication to enhance the military capability of perceived and actual enemies. Furthermore, the system may prove inadequate to control "leaks" by government officials, at least if efforts at control are considered censorship rather than derrial of access.

The second critique would charge that the degree of government control allowed by the equitibrium theory undermines the values of the Jeffersoinan conception. If, for example, government is authorized to keep its plans and processes secret, the countervailing power of the press-in light of its complex incentives-may be insufficient to ensure control and deliberation on the part of the citizenry. To be sure, potential harm to national security or other important interests will sometimes justify secrecy, but the equilibrium approach does not require the government to inake any such showing. The ultinate risk is that the equilibrium theory will fail to guard against self-interested representation or the usurpation of government power by private factions.

54. See infra text accompanying notes 93-99 (discussing systemic impact of government employee waiver of free speech rights). 
There is, in short, no reason to believe that the equilibrium model of the first amendment will ensure a workable accommodation of the interests in disclosure and secrecy, or that it will promote the Jeffersonian conception of free expression. Historical experience under the equilibrium approach suggests that both critiques have been persuasive at different periods. At times the press has been able to publish material that may have caused considerable harm; the Pentagon Papers case arguably is an example. ${ }^{5 S}$ On the other hand, the experience leading up to the Freedom of Information Act produced evidence that government control of undisclosed information may often undermine the system of free expression for no legitimate reason. ${ }^{56}$

The equilibrium theory remains impressionistic and relies on premises that are both unsupported and unlikely. The sharp distinction between rights of access and rights of publication thus rests on unstable foundations. To be sure, political forces may produce partial remedies, of whicls the Freedom of Information Act is an exainple; but there is no assurance that such reinedies will, in conjunction witl the equilibrium theory, produce a sensible system of free expression. All this suggests that the distinction between access and publication is liard to defend and that a system of interest-balancing, informed by the Jeffersonian model, would have important advantages. But before exploring that issue, it will be useful to examine the operation of the equilibrium model in particular contexts.

\section{IV}

\section{Applications: Two Problems in First Amendment THEORY}

The discussion thus far lias suggested that in the abstract, the equilibrium theory is highly vulnerable to attack. This Part of the Article exammes the relationship between the equilibrium theory and two of the more controversial contemporary issues in first amendment doctrine. Botll of these issues press the equilibrium model, thougli in different ways. The first involves government efforts to control disclosure of "technical data" to foreign nationals; the second involves the government's power to regulate the speecl of its own employees. Under the equilibrium model, regulation of technical data appears to be prolibited

55. See supra note 27 .

56. See generally Availability of Information from Federal Executive Agencies: Hearings Before the Special Subcomm. on Government Information of the House Comm. on Government Operations, 84th Cong., 2d Sess. to 86th Cong., 1st Sess. (1956-1959) (exploring problems raised by extensive government secrecy); Freedom of Information: Hearings Before the Subcomm. on Administrative Practice and Procedure of the Senate Comm. on the Judiciary, 88th Cong., 1st Sess. (1964) (same); Freedom of Information Act and Amendments of 1974: Hearing Before the House Comm. on Goverment Operations, 94th Cong., 1st Sess. 236-37 (1975) (statement of Rep. Matsunaga) (same). 
censorship, for it involves the regulation of privately generated information $^{57}$ in circumstances im which it is generally impossible to demonstrate grave harm. Regulation of speech by government employees lies at the boundary between government control of "its" information and censorship. But it may be that this consideration, and the equilibrium model generally, poimt in precisely the wrong direction on botll issues.

\section{A. The Problem of Technical Data}

A number of statutes regulate the disclosure of technical data to foreign nationals, as part of a general effort to prevent foreign countries from obtaining advanced technology. The most important and controversial of these statutes are the Arms Export Control Act, ${ }^{58}$ administered by the Department of State, ${ }^{59}$ and the Export Admimistration Act of $1979,{ }^{60}$ administered by the Department of Commerce. ${ }^{61}$

The Arms Export Control Act is desigued to regulate the export of items, consisting of "defense articles and defense services," the Umited States Mumitions List compiled by the State Department. These items may not be exported without a hicense from the Department. The Act would of course be imeffective if it prohibited only the export of actual arms. The purpose of the statute is to ensure against disclosure of teclinology. Regulations thus require a license for export of "information whicl is directly related to" the production, operation, or maintenance of enumerated armaments as well as "information which advances the state of the art" of sucl1 armaments. ${ }^{63}$ The term "export" is defined quite broadly to mclude disclosure to foreign citizens in the United States, including students attending university lectures. ${ }^{64}$ Certain material is exempted, including information published in journals that are

57. The relevant regulations apply to publicly generated information as well. Such applications will not be discussed liere-althougl, as suggested below, one may doubt whether the two fall in different categories for first amendment purposes. See infra Part IV, Section $B$.

58. Pub. L. No. 90-629, 82 Stat. 1321 (codified as amended primarily at 22 U.S.C. $\S \S 2751$ 2796(c) (1982)).

59. 22 U.S.C. $\$ 2752(b)(1982)$.

60. Pub. L. No. $96-72,93$ Stat. 503 (codified as amended primarily at 50 U.S.C. $\$ \S 2401-2420$ (1982)).

61. 50 U.S.C. $\$ 2414$ (1982). Other statutes regulating technical data are discussed in Comment, National Security Controls on the Dissemination of Privately Generated Scientific Information, 30 UCLA L. REv. 405 (1982).

62. For definitions of these terms, see 22 C.F.R. $\$ \S 120.7,120.8$ (1985).

63. 22 C.F.R. $\$ 120.21$ (1985). The Secretary of Defense is separately authorized to withhold from public disclosure "any teclinical data with military or space application" which may not be exported without a license under the act. Teclinical data are defined for these purposes to include any information that "can be used, or be adapted for use" in the design, production, or maintenance of military or space equipment. 10 U.S.C. $\$ 140$ c (Supp. II 1984).

64. Such regulations liave a severe impact, for approximately $25 \%$ of the engineering and science graduate students in the United States are foreign nationals. See Comment, supra note 61, at 426-27. 
available to the general public. ${ }^{65}$

Similarly, the Export Administration Act is designed to allow regulation of the export of technological information that "could make a significant contribution to the nilitary potential of any country or conibination of countries which would be detrimental to the national security of the United States."66 The provisions of the Export Administration Act are, for present purposes, sinilar to those of the Arms Export Control Act.

The constitutionality of these restrictions will turn largely on whether the information in question is entitled to "full" first amendment protection. Under the equilibriun nodel, the harms invoked by government are for the most part too speculative to support either prior restraint or subsequent punishment. To be sure, disclosure of technical data will in sone cases aid the military efforts of other countries, but the chain of causation is too attenuated to justify prior restraint under the Pentagon Papers standard. ${ }^{67}$

In particular, three uncertamties will generally make it impossible for the governnient to meet the Pentagon Papers standard or to justify a ban under the equilibriun nıdel even if the government's burden were less severe. First, with respect to most exports, it is uncertain that the information will be received by foreign governments at all. Cominunication to foreign nationals-students or private conıanies-does not guarantee communication to foreign governments. Second, even if the information is received, it niay not be put to military use. The other country may have conipeting priorities. It nay be expensive to adapt the information, or adaptation nuy require information that the country lacks. Finally, even if the information is received and put to military use, it will be unlikely to have a significant effect on national security as a whole, even if it produces sone increniental harm. In general, then, the government's justification will not be sufficiently powerful to support the regulations under current doctrine. ${ }^{68}$

65. See 22 C.F.R. $\$ \S 120.18,125.1$ (1985). The statute and regulations do not require any particular state of mind on the part of the exporter, though a court of appeals has implied a requirement that the exporter know or have reason to know that the recipient intends to use the exported information to make or operate articles on the Munitions List. United States v. Edler Industries, Inc., 579 F.2d 516, 521 (9th Cir. 1978).

66. 50 U.S.C. app. $\$ 2401(8)$ (1982).

67. It will be remembered that under that standard, government must show that "disclosure ... will surely result in direct, immediate, and irreparable damage to our Nation or its people." New York Times Co. v. United States, 403 U.S. 713, 730 (1971) (Stewart, J., concurring).

68. Nor is technical data unprotected because its recipients are foreign nationals. It may be that there is no right to receive information from foreigners, see Kleindienst v. Mandel, 408 U.S. 753, 770 (1972), or that foreigners themselves have no first amendment rights while residing outside of the country. The government is not permitted, however, to prevent American citizens from communicating with citizens of foreign countries. 
The critical question then becomes whether scientific information is entitled to full first amendment protection-a question that the Court itself asks in analyzing free speech cases, ${ }^{69}$ but which is foreign to the equilibrium approach. At first glance, the argument for affording such protection seeins quite powerful. First, technical information might in some contexts have a significant bearing on public deliberation. Consider, for example, the relevance of such information to debates over nuclear weapons, the control of carcinogenic substances, or the use of nuclear energy. ${ }^{70}$ Often it is difficult to take responsible positions on such issues without having command of technical matters. ${ }^{71}$

Scientific information is also part of a genuine marketplace of ideas, one in which there is some sort of progress. ${ }^{72}$ Thus it has been remarked that the

significant new concepts of science are often ... the result of association of widely diverse facts and ideas that may not hitherto have seemed remotely connected.

Such ideas as the law of mechanics ... together with the work of Planck on high temperature radiation, led Emstein to postulate the equivalence of mass and energy. ...

69. This mode of analysis is quite clear in the commercial speech context. See, e.g., Virginia State Bd. of Pharmacy v. Virginia Citizens Consumer Council, Inc., 425 U.S. 748, 758-70 (1976). For an analysis arguing that scientific speech should be afforded constitutional protection, see Ferguson, Scientific and Technological Expression: A Problem in First Amendment Theory, 16 HARV. C.R.-.C.L. L. REv. 519 (1981) (scientific speech entitled to first amendment protection according to values underlying commercial speech decisions); Ferguson, Scientific Inquiry and the First Amendment, 64 CoRnell L. REv. 639 (1979) (Court has hinted that scientific speech is protected under first amendment, and such protection is proper); Redish, Limits on Scientific Expression and the Scope of First Amendment Analysis: A Comment on Professor Kamenshine's Analysis, 26 WM. \& MARY L. REv. 897 (1985) (arguing against "low-value" approach to scientific speech).

70. Consider in this regard Robert Dahl's suggestion that "the institutionalization of secrecy has concentrated, in the hands of a few people, control over decisions of a great magnitude for the values of a larger number of persons than in all probability were ever affected by any old-fashioned authoritarian leader." Dahl, Atomic Energy and the Democratic Process, in The Impact of Atomic Energy, 290 ANNALS 1, 2-3 (1953).

71. United States v. Progressive, Inc., 467 F. Supp. 990 (W.D. Wis.), request for writ of mandamus denied sub nom. Morland v. Sprecher, 443 U.S. 709, dismissed, 610 F.2d 819 (7th Cir. 1979), is relevant here. In that case, information on how to make a hydrogen bomb was offered as an integral part of an argument explaining the nature of the crisis produced by the availability of nuclear weapons. In such a case, it would be hard to argue that the government's burden is reduced because scientific information is "nonpolitieal."

72. Consider Oppenheimer's view:

If you are a scientist you believe that it is good to find out how the world works; that it is good to find out what the realities are; that it is good to turn over to mankind at large the greatest possible power to control the world and to deal with it according to its lights and its values.

Oppenheimer rejects any "attempt to treat science of the future as though it were rather a dangerous thing, a thing that must be watched and managed." Address by J. Robert Oppenheimer to the Association of Los Alamos Scientists (November 2, 1945), reprinted in ROBERT OPPENHEIMER: LeTters AND ReCOllections 317-18 (A. Smith \& C. Weiner eds. 1980). 
Yet today, any intelligent military organization, operating under the present security rules, would certainly classify the equivalent of Planck's work so that it would be denied to a potential Einstein. ${ }^{73}$

Communication of scientific information, including technical data, is a crucial mechanism by which science progresses. In this respect, scientific information stands far afield from obscenity, the classic example of "low value" speech. ${ }^{74}$

Technical data will, then, sometimes be part of political speech, and it will contribute to scientific development. Under a Jeffersonian conception of the first amendment, however, large categories of technical data are, in context, far from the center of first amendment concern. Such data may consist of algorithnis, equations, charts, or blueprints. Information of that sort is communicative, to be sure; it involves ideas, and it is "speech." But that speech is not necessarily of the sort to which the Jeffersonian model affords full protection. ${ }^{75}$

Whether and when speech should be considered "low value" is a complex question, but it is possible to isolate a series of factors that both account for the cases and are congenial to the Jeffersonian approach. First, speech that concerns pohitical processes, broadly construed, is treated differently from speech that has little or nothing to do with public affairs. ${ }^{76}$ Second, the purpose of the speaker is relevant: if the speaker is seeking to communicate a political messsage, again broadly construed, he will be treated more favorably than if he is not. Third, the categories of low-value speech tend to represent categorical judgments that in certain areas, government is unlikely to be acting for constitutionally impermissible reasons or to be producing constitutionally inıpermissible harms. In the cases of commercial speech, private libel, and obscenity, for example, one might say that government regulation is peculiarly likely to be based

73. Hearings, supra note 31, at 756 (statement of L. Berkner).

74. See Miller v. California, 413 U.S. 15 (1973); Roth v. United States, 354 U.S. 476 (1957).

75. One might reach this conclusion without defining the notion of "political speech" narrowly, as does Judge Bork. See Bork, supra note 7, at 27-28 (protected speech should not include scientific, educational, commercial, or literary expressions). In particular, much literature should be placed in the category of "political" speech. Meiklejohn believed that literature is a basic part of the "many forms of thought and expression within the range of human communieations from which the voter derives the knowledge, intelligence, sensitivity to human values: the capacity for sane and objective judgment which, so far as possible, a ballot should express." Meiklejohn, The First Amendment Is An Absolute, 1961 SuP. CT. REV. 245, 256. The basic understanding is correct, though the limitation to "ballot" and "voting" unduly restricts the operation of the Jeffersonian model, which offers a broader scope for citizen participation. Under this view, too, scientific speech will often be protected when it is part of the deliberative process. Cf. $i d$. at 257 (listing categories of thought and expression deserving of first amendment protection).

In any event the government's justifications for banning literary speech tend to be very weak. Some technical data stands at the opposite pole in terms of its centrality to the Jeffersonian model and the strength of the government interests supporting regulation.

76. See supra notes $15-18$ and accompanying text. 
on legitimate reasons, and peculiarly unlikely to be a product of selfinterested representation or factional tyranny. Judicial scrutiny is thus more deferential.

Under all three inquiries, technical data will often qualify as speech entitled to less than the highest level of protection. At least generally, the release of such data to foreign nationals does not, and is not imtended to, commumicate a substantive political message. Regulation is not designed to insulate government from criticism or to promote the welfare of self-interested private groups. The context and purpose of the disclosure of techmical data will thus often justify the conclusion that such data may be regulated on the basis of a somewhat less powerful demonstration of harms.

These themes, borrowed from the Jeffersoman understanding, are conventional in first amendunent law, though they are foreign to the equilibrium model as set out by Bickel. Obsceinity, false stateinents of fact, fighting words, and private libel are thus analyzed differently from other forms of speech. But the notion that some speech should be afforded less protection because of its "low value" is highly controversial. The very assessment of value might be thought to call for inquiries that are incompatible with a sensible system of free expression. Such inquiries will also produce hard problems of line-drawing, which should generally be avoided in first ainendment doctrine lest the censor draw the line at the point that best promotes the censor's own interests. Moreover, an assessment of value requires a judgment about the central purposes of the first ainendment. But it is by no ineans universally accepted that the first ainendment protects only or especially political speech, even if "pohtical speech" is very broadly defined.

It is not my purpose here to enter the longstanding debate over the purposes of the first amendment. But it would be hard to develop a system of free expression that did not distmguish categories of speech in accordance with their centrahty to the purposes of the free speech guarantee. A systein that failed to draw such lines would likely be driven to deny full protection to speech that merits it. The burden of justification on government would be weakened in order to allow regulation of (for example) commercial speech, and that weaker burden would by hypothesis have to extend across the board. The alternative would be to adopt a justification requirement so stringent as to forbid regulation that is currently accepted, on the theory that the burden applied to regulation of political speech should be extended to (for example) commercial speech. In these circumstances the inost likely outcoine is that judgments about value would be made tacitly and that the articulated rationale for decisions would not reflect an assessinent of all of the factors thought relevant by the Court. 
Once distinctions are admitted among categories of speech, the question becomes on what those distinctions will be based. It will be sufficient to suggest that the Jeffersomian model, in its emphasis on political speech, has history on its side; ${ }^{77}$ that it is responsive, as other theories are not, to the contexts in which government is likely to be least trustworthy as an arbiter; ${ }^{78}$ and that it may well point to what is most distinctive about speech as a human activity. ${ }^{79}$

If the emphasis on political speech is accepted, at least some categories of techmical data will be near the periphery of first amendment concern. In this context, any solution is imperfect, and perhaps the best way to make the argument is to point out the weaknesses of the alternative. If technical data is to be treated the same as political speech, the government will face a heavy burden of justification for suppressing the information. But an approach that would require the same showing of harm to ban both pohitical speech and mathematical equations is likely to lead to serious anomalies. On the one hand, a conclusion that export of technical data can be banned would require a considerable loosening of the Pentagon Papers standard. The relaxation of the standard would mean that a lesser showing of harm would be required to ban political speech, a result that is imconsistent with the course of first amendment doctrine since World War II. ${ }^{80}$

On the other hand, a conclusion that technical data may not be restricted because government is unable to meet the Pentagon Papers standard will have broad implications. The regulations in question are directed at export not only of technical data, but also of the underlying products-items on the nuunitions list and other material that is adaptable to military use. The reason for the prohibition of export of these products is precisely their "communicative impact." The government's fear is that if the materials are exported, they might be reproduced. The technical data and the products stand on the same footing.

This conclusion suggests that under normal first amendment principles, the prohibition of the export of the materials is constitutionally suspect. Regulations of conduct that are aimed at its communicative content are properly treated as regulations of speech. ${ }^{81}$ If this is correct,

77. See generally L. LEVY, supra note 46.

78. See F. SCHAUER, supra note 7.

79. 1 J. Habermas, The Theory of Communicative Action 99-101, 286-88, 306-08 (McCarthy trans. 1984); Pitkin, supra note 8, at 342-46.

80. See J. ELY, supra note 12, at 105-16 for a review of such doctrine and for an argument in favor of protecting all speech except that falling in a few specified, narrow categories.

81. See United States v. O'Brien, 391 U.S. 367 (1968). To be sure, there may be no first amendment issue if the oniy communicative impact is aimed at people in another country. $C f$. Kleindienst v. Mandel, 408 U.S. 753 (1972) (denial of visa to Marxist journalist does not violate first amendment rights of potential American listeners). But the provisions governing export of both the arms and the data extend to communicative impact within the United States. 
the government must justify the prohibition of exporting not only techmcal data but also items on the munitions list by meeting the Pentagon Papers standard. As already noted, that standard cannot be satisfied. ${ }^{82}$ It would be unfortunate imdeed if it became necessary to revive the largely discredited distinction between speech and conduct in order to permit the government to regulate exports of items on the munitions list.

To say that some technical data may be regulated on the basis of a less powerful justification is hardly to say that scientific information is deprived of first amendment protection. In many cases, such information will be of central first amendment concern. Examples are scientific information about the risks of nuclear power, the status of national defense, or the incidence of cancer produced by various environmental hazards. To be sure, there will be difficnlt intermediate cases for the courts-as there are under current doctrime-but here as elsewhere, the existence of such cases is not a sufficient reason to abandon an otherwise sensible distinction. The basic question is whether technical data are being released as part of a political communication, and in almost all cases that will arise in the real world, that question will be easily answered.

Moreover, the conclusion that some technical data may be banned on a lesser showing of harm does not imply that the government has license to ban scientific information whenever it chooses. It inust still ineet a considerable burden, as the commercial speech cases suggest. ${ }^{83}$ But if the techrical data do not implicate concerns central to the Jeffersonian model, that burden should be substantially lower than the Pentagon Papers standard. Thus, for exainple, government sliould be able to regulate the export of technical data when it is able to show that the export is likely to bring to an adversary's attention information that has probable military apptication and that will substantially enhance the adversary's military position. This standard is inore deferential than that in Pentagon Papers, but it still imposes a significant burden on government. The standard will, of course, leave difficult cases in application; the point is not to suggest how each case should be decided but instead to explain why the burden on government should be inore lenient.

These considerations suggest that some categories of technical data may be regulated consistently with the first amendment, even if the data have been generated privately. This conclusion leads to a more general

82. See supra text accompanying notes 67-68.

83. See, e.g., Virginia State Bd. of Pharmacy v. Virginia Citizens Consumer Council, Inc., 425 U.S. 748 (1976) (commercial speech entitled to first amendment protection). But see Posadas de Puerto Rico Associates v. Tourism Co. of Puerto Rico, 106 S. Ct. 2968 (1986) (legislative power to ban casino gambling entirely "necessarily includes the lesser power to ban advertising of casino gambling"). 
point. A significant defect in the equilibrium model is that it does not incorporate the notion that there should be gradations in the government's burden of justification, gradations that depend on the nature of the speech sought to be regulated.

\section{B. Government Employees}

The problem of controlling speech by government employees has received considerable attention in recent years, especially in connection with the increased use of "secrecy agreements." The Central Intelligence Agency, the Federal Bureau of Investigation, and some offices within the Departinent of Defense currently provide that past and present employees may not publish inaterial deriving from their employment without prior government authorization. ${ }^{84}$ In 1983 President Reagan issued, and later withdrew, a set of regnlations that would have required hundreds of thousands of federal employees having access to classified information to sign prepublication review agreements. ${ }^{85}$

The problems raised by speech by government employees span a wide range, mcluding subversive advocacy, criticism of the government, and, most important for present purposes, disclosure of information acquired during government employinent. The remedies that government might seek are also quite varied. Among the possibilities are a blanket prolibition, a requirement of prepublication review ("preclearance"), restrictions on political activity, criminal penalties, discliarge, civil fines, and restitution of any profits gained from the speech in question. These restrictions inight be applied to current or former government einployees.

The current attempts to control the speech of government employees do not fit comfortably into the equilibrium model. If an employee decides to breacl a secrecy agreement or to divulge information acquired in confidence, one inight conclude that the government has failed in its efforts to preserve secrecy, and that the information cannot be suppressed except in a dire emergency. On the other hand, government does not exist apart from its agents, and if its methods of controlling its einployees

84. See Prepublication Review and Secrecy Requirements Imposed Upon Federal Employees: Hearings Before the Subcomm. on Civil and Constitutional Rights of the House Comm. on the Judiciary, 96th Cong., 2d. Sess. (1980). Thus, for example, CIA employees must agree to submit for prior review

all writings and scripts or outlines of oral presentations intended for nonofficial publication, including works of fiction, which make any mention of intelligence data or activities, or contain data which may be based upon information classified pursuant to law or Executive order.... No steps will be taken toward publieation until written permission to do so is received....

Id. at 24 (statement of Alice Daniel) (footnote omitted).

85. National Security Directive No. 48 (March 11, 1983), reprinted in 5 A.B.A. STANDING COMm. ON LAW ANd NAT'L SECURITY INTELligenCE ReP. 1 (1983). 
are only hortatory, the equilibrium model may break down. If the government were permitted to obtain a prepublication review agreennent, a legal remedy for its violation might be treated as a permissible means of denying nongovernmental persons or entities access to the government's information. In this respect, a legal remedy could be understood as a mechanism by whicl1 government keeps its information private. In any event, as we sliall see, the awkward place of speecl by government employees in the equilibrium model accounts for much of the doctrinal confusion.

Here, as in the case of technical data, there are few decisions on the subject. The equilibriuin nodel, enbodied in the notion that government may control "its" information, played an important role in the leading case on the point, Snepp v. United States. ${ }^{86}$ In that case, the Court uplield a CIA agreement that prohibited Snepp from publishing any information, whether or not classified, about the CIA without obtaining clearance froin the government. According to the Court, the agreennent was a "reasonable means" of protecting "tlie secrecy of information inportant to our national security and the appearance of confidentiality so essential to the effective operation of our foreign intelligence service." 87

The decision in Snepp, lowever, was a narrow one. It involved the CIA, and the government has a powerful interest in controlling speecl by CIA einployees in higlt of their access to information wliose disclosure could produce severe harms of the sort catalogued above. Moreover, the remedy in question was not an outriglit ban. It involved instead preclearance, following whicl publication miglit well have been permitted, and a constructive trust for profits gained tlirougl breach of the agreeinent. ${ }^{88}$

As Snepp reveals, the central question raised by restrictions on the speech of government employees involves the government's burden of justification. Here, as in the case of technical data, the government will alinost always ${ }^{89}$ be unable to meet the Pentagon Papers standard. The information in question rarely would produce certain grave harm. Moreover, if the governinent attempted to regulate the speech of private citizens as much as it does that of its employees, the regulation would certainly be unconstitutional. The question then becomes why the burden of justification should be lowered simply as a result of the speaker's status as a past or present government employee. Notably, it will usually

86. 444 U.S. 507 (1980).

87. Id. at $509 \mathrm{n} .3$.

88. Id. at $510-16$.

89. In some circumstances, of course, an employee may attempt to disclose information that is vital to national security, but these cases will be rare. 
be impossible to argue that the speech in question is low value. Disclosures by government employees will usually be central to the Jeffersonian conception, for they will relate directly to the operations of government.

Arguments for restricting the speech of government employees tend to involve three separate claims: that employees have waived their rights; that government "owns" certain information; and that governinent has distinct interests as an employer that justify regulation. Of these justifications, only the third relates to the justifications for regulation discussed in Part III above; and none is sufficient to justify the current restrictions on employee speech.

\section{The Argument from Waiver}

Under this approach, the issue is a simple one. At least where there is an exphicit agreement, and perhaps where there is a regulation on the point, government einployees voluntarily relinquish their rights of free speech. Snepp, for example, had signed an agreement to submit his writings to prepublication review. In general, constitutional rights inay be waived, ${ }^{90}$ and the same conclusion should be appropriate here. ${ }^{91}$ The claim is closely related to the equilibrium approach; it derives from an understanding that government may control information within its own hands.

The argument from waiver is exceptionally broad. It would permit the government to condition employment on whatever terms it sees fit, as long as it can obtain an agreement from the einployee. But the Court has generally rejected the distinction between rights and privileges in constitutional law. ${ }^{92}$ The usual reason is that conditions imposed on privileges permit the government to do indirectly what it may not do directly and exert impermissible "pressure" on constitutional rights. Under this approach, the issue is not whether the einployee is better off as a result of the employment contract, but whether the right is pressured in a way that it would not be if government had not imposed the condition. When government makes preclearance of writings a condition of employment, the riglit to freedoin of speecli is curtailed, even if the employee accepts the agreeinent.

This point suggests that even voluntary waivers interfere with rights

90. See, e.g., Johnson v. Zerbst, 304 U.S. 458 (1938) (waiver of right to counsel).

91. See Easterbrook, Insider Trading, Secret Agents, Evidentiary Privileges, and the Production of Information, 1981 SUP. CT. REv, 309, 344-52 (arguing that contract in Snepp involved valid waiver of first amendment rights).

92. See Van Alstyne, The Demise of the Right-Privilege Distinction in Constitutional Law, 81 HARV. L. REV. 1439 (1968) (arguing that implications of distinction between rights and privileges has been gradually eroded). But of. Kreimer, Allocational Sanctions: The Problem of Negative Rights in a Positive State, 132 U. PA. L. REv. 1293, 1308 n.43 (1984) (distinction between rights and privileges has continued vitality). 
of free speech, but it does not explain why these interferences should be proscribed when the employee is willing to acquiesce. The explanation lies in the systemic or structural consequences of governinent purchases of first amendment rights, consequences that the argument from waiver ignores. $^{93}$ As we have seen, the first ainendment is largely a structural provision, "guarding against self-interested representation and the control of governinent by powerful private groups. ${ }^{94}$ Its purpose is not only to protect private autonoiny, but also to preserve a certain form of government. Citizens may often find it in their interest to give up rights of free speech in exchange for benefits from government. For inany, these rights are not extrenely valuable as individual possessions. But if government is permitted to obtain enforceable waivers, the aggregate effect inay be considerable, and the deliberative processes of the public will be skewed. Self-interested representatives will be inore able to entrench theinselves, and private groups will be subject to less control. Waivers of first ainendinent rights thus affect people other than government employees, and effects on third parties are a classic reason to proscribe waivers.

The analogy here is to government purchases of voting rights, ${ }^{95}$ which are impermissible even if voters willingly assent. To be sure, the systemic effects might be sinall in light of the large number of einployers other than the government. ${ }^{96}$ But the breadth of government activity suggests that the impact is unlikely to be minimal, even if government does not liave "Inarket power" in the sense of antitrust law. Moreover, it nnay well be that government skewing of deliberative processes is inpermissible even if the extent of the effect is unclear. ${ }^{97}$

This argunnent inplies that like the right to vote, the right to free speech is not alienable. ${ }^{98}$ There is a social interest in ensuring against governinent purchases of decisionmaking processes, even if einployees, in their capacity as einployees, are better off as a result. To be sure, market pressures may act to some degree as a safeguard against government efforts to purchase employee speech; einployees will deinand some sort of

93. See Kreimer, supra note 92, at 1391; cf. R. DwORkiN, A MATter OF Principle 395-97 (1985) (emphasizing rights of listeners as basis for rejecting waiver arguments).

94. See supra text accompanying notes 9-13.

95. See Epstein, Why Restrain Alienation?, 85 Colum. L. Rev. 970, 984-88 (1985).

96. Cf. Easterbrook, supra note 91 , at 347 (arguing large number of employers gives employee choice of job packages, and employee choosing package waiving first amendment rights shows belief that package is advantageous).

97. Cf. M. WALzer, SPheres OF Justice 100-03 (1983) (discussing rights that should not be traded through markets).

98. See R. DworkiN, supra note 93, at 395-97 (pointing to rights of listeners and justifying inability to waive rights of equality). Rights in the criminal justice system, by contrast, generally do not raise systemic issues; they are best understood as individual rights rather than separation of powers provisions. The issue then becomes whether some individual rights are not waivable despite the absence of systemic effects. See id.; Kreimer, supra note 92. 
fee for the relinquishment of first amendment rights. But there is no reason to believe that the amount that employees will demand is enough to guard against substantial infringements on the system of free expression.

These considerations raise a more general point. To a large extent the Constitution, including the first amendment, operates as a constraint on the reasons for government action. ${ }^{99}$ In some contexts the only interest supporting a secrecy agreement will be the desire to immunize government from criticism or exposure. If in suppressing employee speech government is acting for a reason that is constitutionally proscribed, it is irrelevant that the employee may have acquiesced. And even if a legitimate interest might be identified, it will be outweighed by the systemic consequences of government purchases of first amendment rights. Thus far, then, government employees should be treated the same as citizens generally. All this is to suggest that in the context of restrictions on the speech of government employees, arguments from waiver are unpersuasive.

\section{The Argument from Ownership: The “Government's" Information}

A second argument for permitting broad restrictions on speech by governinent employees can be derived directly from the equilibrium model. By hypothesis, the employee has received information solely because of government employinent. It is proper for government to structure its relations with its agents so as to prevent disclosure of information to which neither they nor members of the public have an antecedent right. Permitting government to retain its information is a reasonable accominodation of the interests in disclosure and secrecy.

This claim is narrower than the argument from waiver, for it would not permit a prohibition on publication of materials that do not include information obtained during employment with the government. The class of permissible prohibitions is therefore smaller. The argument does, however, permit some form of preclearance in order to ensure that the government's information is not included in the employee's writings.

This argument relies on property-based notions of information ownership, notions that treat the government like a private citizen who owns information. But the government is an abstraction. It need not have rights in information akin to those of a private citizen. Whether it should be permitted to prevent the relevant information from reaching the public, if a past or present employee wants to disclose it, should not depend on labels having to do with "ownership." The precedents here

99. See Stone, Content Regulation and the First Amendment, 25 WM. \& MARY L. REv. 189, 227-30 (1983); Kreimer, supra note 92, at 1312. 
are the public forum cases, which have also created a right of access. ${ }^{100}$ These decisions turn on the understanding that government ownership of property does not necessarily dispose of a first amendment claim. Government must justify restrictions by reference to something other than ownership. ${ }^{101}$

In order to assess the argument from ownership, it is useful to explore the analogy to private law. Corporations and individuals are entitled to obtain damages for disclosure of information in breach of contract; ${ }^{102}$ why should government be treated differently? The answer lies in the reasons for permittimg secrecy in the two cases. For a private corporation, information is an asset like any other form of property. Its value rests largely in its unavailability to competitors, and disclosure in violation of contract is a form of theft, enabling those competitors to profit. Information is therefore protected for some of the same reasons that justify protection of private property in general.

Information in the hands of the government, however, is not an asset whose "value" hes in its unavailability to competitors. The public is hardly the government's "competitor," but is instead its ultimate source of authority. ${ }^{103}$ In addition, the information that a private corporation seeks to suppress is usually far from the center of first amendment concern; it will involve trade secrets, competitive strategies, or claims of misinanagement. Speech by government employees, by contrast, is generally near the heart of the Jeffersonian model. ${ }^{104}$

Similar considerations distinguish contracts between mdividuals to guard against disclosure of private information. In such cases, the notion of private ownership is plausible, and the first amendment interest is weak. When government tries to enforce a secrecy agreement, however, the opposite is true: the speech often concerns public affairs and notions of "ownership" are implausible. The analogy to private ownership of information thus breaks down because the arguments that support such ownership are mapplicable to government.

The first amendment question should therefore turn not on notions of information ownership, but on what sort of justification the govern-

100. See Grayned v. City of Rockford, 408 U.S. 104, 115 (1972) ("The right to use a public place for expressive activity may be restricted only for weighty reasons"); see also Stone, Fora Americana: Speech in Public Places, 1974 Sup. Cr. REv. 233, 255; Note, The First Amendment Right To Gather State-Held Information, 89 YALE L.J. 923, 934-36 (1980).

101. See Grayned, 408 U.S. at 119 (prosecution under antinoise ordinance is constitutional as ordinance furthers government interest in undisrupted school day); Stone, supra note 100, at 251-52, 254 ; Note, supra note 100 , at $934-36$.

102. See Zoecon Industries v. American Stockman Tag Co., 713 F.2d 1174 (5th Cir. 1983).

103. To be sure, corporations may be able to suppress the disclosure of information to their shareholders, who stand in a position in relation to the corporation that is in some respects akin to that of the people in relation to their government. But even here, the interests are quite different.

104. See R. DWORKIN, supra note 93 , at 395-96. 
ment is able to use to support the restriction. This argument of course amounts to a fundamental attack on the equilibrium theory, which depends on the notion that some information should be treated as belonging to the government.

Even if notions of ownership are accepted, a preclearance mechamism is often too broad to accomplish the government's permissible goals. It is one thing to say that preclearance is required for speech that may contam classified information and that is produced by a former official of the CIA. In their day-to-day employment, CIA officials are pecuharly likely to use mformation whose disclosure would cause the sorts of harms described in Part II above. It is quite another thing to say that preclearance is required whenever a former employee having access to classified information seeks to publish something that relates to the government. In the latter case, preclearance may deter and delay a wide variety of speech, and those costs may not be justified by a remote possibility that dangerous information may be released. Any such possibility can be controlled through less restrictive means, including preclearance when classified information is included and subsequent punishment for disclosure of damaging information.

To say this is not to deny that employees owe a fiduciary duty to the government and that ethical obligations should generally prevent government employees from disclosing confidential information. Indeed, personal loyalty and the perception of obligation probably explain why the government only rarely needs to impose sanctions for disclosure on past or present employees. These ethical obhgations argue in favor of a refusal to confer legal remedies on the government. Legitimate interests can almost always be served without resorting to censorship.

In any event, the first amendment question should turn not on notions of information ownership, but on what sort of justification the government is able to urge im support of the restriction. The fact that the employee obtamed the information as a result of government employment provides no independent reason for restricting the right to speak.

\section{Interests as an Employer}

A third argument in favor of restricting the speech of government employees is that the government has interests as an einployer that justify some regulation of speech that could not be imposed if the speaker were a private citizen. The leading case is Pickering $y$. Board of Education. ${ }^{105}$ The issue there was whether a public school could discharge a teacher for sending a letter to a local newspaper challenging a proposed tax increase and criticizing the past revenue-raising efforts of the public

105. 391 U.S. 563 (1968). 
schools. The Court invalidated the discharge, noting that the statement was not shown to have "impeded the teacher's proper performance of his daily duties in the classrooin or to have interfered with the regular operation of the schools generally." 106 The state as employer thus had no distinct interest that would justify the imposition of sanctions on the employee.

The distinction between government as employer and government as censor points to the appropriate considerations. At a minimum, government should not be permitted to impose sanctions on employees because of their speech unless it can identify distinct einployer-related interests. This category of interests, however, is not self-defining. Two questions are relevant here: whether the government has distmct einploymentrelated interests that justify dismissal; and whether those interests are sufficiently weighty to justify the resulting restriction of speech.

In its capacity as employer, the government has two interests that coine up in inany contexts: the desire to avoid disruption of working relationships and the need to set out a uniform official position. Thus, the government might argue that any expression of criticisin by current employees prejudices relationships with superiors. This view was rejected in Pickering. ${ }^{107}$ Government has an institutional interest in exaggerating the extent to which speech that is critical of current pohcies, or that discloses niformation, interferes with the einployınent relationship. Here, as elsewhere in first amendinent doctrine, it will be necessary to examine with care any claims either that a close working relationship will no longer be possible as a result of the speech or that uniformity is required.

Of course, the fact that the einployee makes policy is a relevant consideration, ${ }^{108}$ and if the employee is in a position to speak for the United States, the claim for uniformity becomes more powerful. For example, no constitutional question would be raised if the President discharged a Secretary of Defense who criticized executive policy in the Middle East. The executive branch has an interest in presenting a uniform position on matters of public importance, and open criticism might interfere with that interest.

To explore the contours of employment-related interests in detail would take the discussion far froin the central issue of governmental control of information. For present purposes, it will be sufficient to suggest that restrictions justifiably imposed because of government's interest as

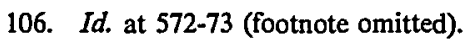

107. Id. at 570 .

108. See Branti v. Finkel, 445 U.S. 507, 517-18 (1980); Elrod v. Burns, 427 U.S. 347, 367-68 (1976) (plurality opinion); Coven, The First Amendment Rights of Policymaking Public Employees, 12 Harv. C.R.-C.L. L. Rev. 559 (1977). 
an employer will be much narrower than those that would be supportable under either of the two arguments examined above. In addition, the distinction between government as employer and government as censor suggests that the class of restrictions on speech by those no longer in government employment should be quite narrow, probably similar to the class of restrictions that might be imposed on those who had never been employed by the government. When the speaker has left the government, the usual justifications-the need to present a uniform position, the value of preserving good working relations, and so forth-drop out. There are also important implications liere with respect to current employees. Most significantly, the employer-related interests can generally be vindicated by discliarge. They will not usually support any sanction other than dismissal.

These considerations suggest that restrictions on speech by government employees will generally be difficult to justify. Witl respect to former employees, restrictions should almost always be invalid unless grave harm would be produced by disclosure- the same standard that governs private speakers. ${ }^{109}$ With respect to current employees, the only remedy is discharge, and the question is whether distinctive employment-related interests justify that remedy when it would infringe upon freedom of speecl.

\section{CONCLUSION}

The Jeffersonian understanding of free expression stresses the value of citizen deliberation in ensuring against self-imterested representation and control of government by powerful private groups. Botl in general and $m$ its concrete applications, the equilibrium model of the first amendment is unlikely to promote eitler goal. It disregards the complex character of the relevant institutional incentives; it ignores the fact that one or the otlier of the countervailing forces may have insufficient power; and it fails to present a baseline from which to decide whetler the conflict between secrecy and disclosure lias produced a justifiable result.

Exploration of the more particular questions raised by government control of technical data and of speech by government employees suggests furtlier defects in the equilibrium model. Before reaching the issue of justification, it is necessary to decide whether the speech in question is entitled to full first amendment protection or may instead be regulated on the basis of a somewhat less powerful slowing. I have suggested that at least some technical data may be so regulated. Moreover, regulation of speecl by government employees is frequently justified by the equilib-

109. In limited contexts, such as that involving the CIA, this rationale may support preclearance; in any event, this is the most powerful argument in favor of the result in Snepp. 
rium model. The traditional arguments for such regulation, however, are unpersuasive. In particular, the notion that some information is "owned" by the government is unacceptable.

These considerations suggest that the equilibrium theory should be modified in four ways. First, the burden of justification imposed on the government should vary-as it does in current law-with the nature of the speech at issue. Second, the notion of a governinental "property interest" in information should, at least for most purposes, be rejected. Third, most restrictions on disclosure of information by government employees should be discarded: ethical obligations, in conjunction with the power to discharge when employer-related interests are at stake, generally will serve as a sufficient safeguard. Finally, in some circumstances a system of free expression is unlikely to work well in the absence of a right of access to information held by government.

To say all this is not to suggest that the first amendment inposes a general obhigation of disclosure on the part of the government. As an attempted accommodation of the interests in secrecy and disclosure, however, the equilibriuin inodel rests on unsupported premises and oversimplifies complicated problems. If a solution is to be found for the problem of government control of information, it will be necessary to look elsewhere.

The approach suggested here would draw on the Jeffersonian model of free expression, the distinction between categories of speech, and, perhaps most important, a particularized understanding of the contexts in which interests in disclosure and secrecy are likely to be powerful. Such an approach would be most likely to recognize the occasional need for secrecy without compromising the underlying principles of public deliberation and self-government. 
